\title{
Carbon Dioxide Capture Chemistry of Amino Acid Functionalized Metal-Organic Frameworks in Humid Flue Gas
}

\author{
Hao Lyu, Oscar Iu-Fan Chen, Nikita Hanikel, Mohammad I. Hossain, Robinson W. Flaig, Xiaokun Pei, Ameer \\ Amin, Mark D. Doherty, Rebekah K. Impastato, T. Grant Glover, David R. Moore, Omar M. Yaghi*
}

\begin{abstract}
Metal-organic framework-808 has been functionalized with 11 amino acids (AA) to produce a series of MOF-808-AA structures. The adsorption of $\mathrm{CO}_{2}$ under flue gas conditions revealed that glycine- and DL-lysine-functionalized MOF-808 (MOF-808-Gly and -DL-Lys) have the highest uptake capacities. Enhanced $\mathrm{CO}_{2}$ capture performance in the presence of water was observed and studied using single-component sorption isotherms, $\mathrm{CO}_{2} / \mathrm{H}_{2} \mathrm{O}$ binary isotherm, and dynamic breakthrough measurements. The key to the favorable performance was uncovered by deciphering the mechanism of $\mathrm{CO}_{2}$ capture in the pores and attributed to the formation of bicarbonate as evidenced by ${ }^{13} \mathrm{C}$ and ${ }^{15} \mathrm{~N}$ solid-state nuclear magnetic resonance spectroscopy studies. Based on these results, we examined the performance of MOF-808-Gly in simulated coal flue gas conditions and found that it is possible to capture and release $\mathrm{CO}_{2}$ by vacuum swing adsorption. MOF-808-Gly was cycled at least 80 times with full retention of performance. This study significantly advances our understanding of $\mathrm{CO}_{2}$ chemistry in $\mathrm{MOF}$ by revealing how strongly bound amine moieties to the MOF backbone create the chemistry and environment within the pores, leading to the binding and release of $\mathrm{CO}_{2}$ under mild conditions without application of heat.
\end{abstract}

\section{INTRODUCTION}

The carbon dioxide capture problem is of paramount societal importance. ${ }^{1,2}$ Although aqueous amine solutions are currently being used to capture $\mathrm{CO}_{2}$, they require significant energy input because of the high heat capacity of water and suffer from loss of amines. ${ }^{3-6}$ Porous solid-state materials are being studied for their potential in offering a platform for mounting amines and foregoing the heat requirement of aqueous solutions. ${ }^{7-9}$ In this regard, materials such as carbon, ${ }^{7,10}$ zeolites, ${ }^{11}$ silica, ${ }^{12-15}$ resins, ${ }^{16,17}$ covalent organic frameworks, ${ }^{18}$ and metal-organic frameworks (MOFs), ${ }^{19-23}$ are being investigated [as summarized in Table 1, see Table S1 in the Supporting Information (SI) for more detailed comparison]., ${ }^{70,19,24-28}$ At present, they all fall short of meeting the stringent performance requirements: high uptake capacity, high selectivity, low regeneration energy, fast kinetics, and long cycling lifetime. ${ }^{29,30}$ We believe that in order to solve the $\mathrm{CO}_{2}$ problem, significant efforts are required in understanding the $\mathrm{CO}_{2}$ chemistry in the pores of such materials and in using this knowledge to build viable structures.

Along these lines, we focus on MOFs and report a series of eleven amino acid functionalized MOF-808 structures (MOF-808-AA), in which the amino acid moieties are strongly bound to the backbone. We find that this construct creates an environment inside the pores where $\mathrm{CO}_{2}$ uptake under humid conditions leads to the formation of bicarbonates, and therefore requiring no application of heat to regenerate the material. In this way, application of rough vacuum is sufficient to remove the $\mathrm{CO}_{2}$ and obviate the need for heating customarily used in aqueous amines and even some solid sorbents.

We and others have appended amines as coordinatively or covalently bound functionalities into MOFs. ${ }^{20,21,31-36}$ Specifically, MOF74 has been used in obtaining high capacity for $\mathrm{CO}_{2}$ uptake. In $\mathrm{Mg}$ MOF-74 [termed $\mathrm{Mg}_{2}$ (dobdc), dobdc = 2,5-dioxidophenylene-1,4- dicarboxylate], the amines are bound directly to the $\mathrm{Mg}^{2+}$ to make a weak bonding interaction. Although this interaction allows for high $\mathrm{CO}_{2}$ uptake mechanism, it is the Achilles' heel of the material as it results in (1) ease of hydrolysis of the MOF backbone, and (2) competition of water to $\mathrm{CO}_{2}$ for $\mathrm{Mg}^{2+}$ sites, and therefore the loss of amines. ${ }^{35,37}$ Furthermore, the Mg-MOF-74 system and their derivatives require heating to $140-240^{\circ} \mathrm{C}$ for regeneration. ${ }^{21,32-35}$ Here, we use a robust MOF-808 $\left[\mathrm{Zr}_{6} \mathrm{O}_{4}(\mathrm{OH})_{4}(\mathrm{BTC})_{2}(\mathrm{HCOO})_{6}, \mathrm{BTC}=\right.$ 1,3,5-benzenetricarboxylate] system ${ }^{38}$ and bind the amino acids through their carboxylates to $\mathrm{Zr}(\mathrm{IV})$ centers to create $\mathrm{Zr}(\mathrm{IV})$ carboxylate interactions, which are 2-3 times stronger than the $\mathrm{Mg}$ (II)-amine interactions. ${ }^{39-41}$ The fact that the amino residue of the amino acid is dangling into the pores creates a basic environment for $\mathrm{CO}_{2}$ binding in the presence of water. This structural design prevents water or $\mathrm{CO}_{2}$ from interfering with the bond between $\mathrm{Zr}$ (IV) and the carboxylate of the amino acids.

In this study, we used MOF-808 as the basis for generating the amino acid functionalized forms. We measured and confirmed their enhanced $\mathrm{CO}_{2}$ capture performance in the presence of water through sorption studies. These involved single-component sorption isotherms, $\mathrm{CO}_{2} / \mathrm{H}_{2} \mathrm{O}$ binary sorption isotherms, and dynamic breakthrough experiments. We further explored the mechanistic aspects of $\mathrm{CO}_{2}$ binding in the presence of water and confirmed the formation of bicarbonate using evidence from solid-state nuclear magnetic resonance (NMR) spectroscopy. The bicarbonate formation is further corroborated by the ease with which $\mathrm{CO}_{2}$ can be removed by vacuum, and this led us to apply the $\mathrm{CO}_{2}$ capture and release process in vacuum swing adsorption (VSA). ${ }^{42,43}$ A member of the MOF-808AA series was subjected to a simulated coal flue gas and found to take up $\mathrm{CO}_{2}$ and release it without heating. These studies, for the first time, combine humidity-enhanced $\mathrm{CO}_{2}$ uptake and low-energy vacuum swing adsorption processes for post-combustion $\mathrm{CO}_{2}$ capture. 
Table 1. Overview of $\mathrm{CO}_{2}$ Capture Properties for State-of-the-Art Sorbents

\begin{tabular}{|c|c|c|c|c|c|}
\hline \multicolumn{2}{|l|}{\begin{tabular}{|l|} 
Sorbent \\
Classes
\end{tabular}} & $\begin{array}{l}\mathrm{CO}_{2} \text { Uptake }^{\dagger} \\
\text { Dry/Humid }\end{array}$ & \begin{tabular}{|l} 
Binding \\
Mechanism
\end{tabular} & $\begin{array}{l}\text { Regeneration } \\
\text { Conditions }\end{array}$ & $\begin{array}{l}\text { Operational } \\
\text { Challenges }^{\ddagger}\end{array}$ \\
\hline \multicolumn{6}{|c|}{ Physisorbents } \\
\hline \multicolumn{2}{|l|}{ Carbon } & $\mathrm{L} / \mathrm{L}(\downarrow)$ & Physisorption & $25-100^{\circ} \mathrm{C} /$ Vacuum & Low cyclability \\
\hline \multicolumn{2}{|l|}{ Zeolites } & M to $\mathrm{H} /$ None $(\downarrow)$ & Polar interaction & $120-250^{\circ} \mathrm{C} /$ Vacuum & Sensitivity to humidity, high regeneration $\mathrm{T}$ \\
\hline \multirow{2}{*}{\multicolumn{2}{|c|}{ MOFs }} & $\mathrm{H} / \mathrm{L}(\downarrow)$ & Open metal sites & $100-200^{\circ} \mathrm{C}$ & $\begin{array}{l}\text { Hydrolysis, low uptake in humidity, high } \\
\text { regeneration T }\end{array}$ \\
\hline & & $\mathrm{H} / \mathrm{H}(\downarrow)$ & Polar interaction & $150-350^{\circ} \mathrm{C} /$ Vacuum & Hydrolysis, high regeneration $\mathrm{T}$ \\
\hline \multicolumn{6}{|c|}{ Chemisorbents } \\
\hline \multicolumn{2}{|c|}{ Hydroxides } & $\mathrm{H}$ & Carbonate & $400-1000^{\circ} \mathrm{C}$ & Solid management, high regeneration $\mathrm{T}$ \\
\hline \multicolumn{2}{|c|}{ Carbonates } & M & Bicarbonate & $150-350^{\circ} \mathrm{C}$ & Pore blockage, high regeneration $\mathrm{T}$ \\
\hline \multirow{3}{*}{$\begin{array}{l}\text { Amine } \\
\text { Liquids }\end{array}$} & Monoethanolamine & $\mathrm{H} / \mathrm{H}(\uparrow)$ & Carbamate-bicarbonate & $90-100^{\circ} \mathrm{C}$ & Amine loss, corrosion, amine oxidation \\
\hline & Amino acid salts & $\mathrm{M} / \mathrm{M}(\uparrow)$ & Carbamate-bicarbonate & $90-100^{\circ} \mathrm{C}$ & Amine loss, amine oxidation \\
\hline & Aminosilicones & $\mathrm{M}$ to $\mathrm{H} / \mathrm{M}$ to $\mathrm{H}(\uparrow)$ & Carbamate-bicarbonate & $80-150^{\circ} \mathrm{C}$ & Amine loss, amine oxidation, urea formation \\
\hline \multirow{4}{*}{$\begin{array}{l}\text { Grafted } \\
\text { Amines }\end{array}$} & Resins & $\mathrm{M}$ to $\mathrm{H} / \mathrm{M}$ to $\mathrm{H}(\uparrow)$ & Carbamate-bicarbonate & $120^{\circ} \mathrm{C}$ & High regeneration $\mathrm{T}$ \\
\hline & Silica & $\mathrm{M}$ to $\mathrm{H} / \mathrm{M}$ to $\mathrm{H}(\uparrow)$ & Carbamate-bicarbonate & $110^{\circ} \mathrm{C}$ & Capacity loss (urea formation) \\
\hline & MOFs, appended & $\mathrm{H} / \mathrm{H}(\uparrow$ or $\downarrow)$ & Metal Carbamate & $100-180^{\circ} \mathrm{C}$ & Hydrolysis, high regeneration $\mathrm{T}$, amine loss \\
\hline & MOFs, functionalized & $\mathbf{M} / \mathbf{M}(\uparrow)$ & Carbamate-bicarbonate & $70-140^{\circ} \mathrm{C} /$ Vacuum & Hydrolysis, high regeneration $\mathrm{T}$ \\
\hline
\end{tabular}

${ }^{+}$Qualitative ranges of general uptake values indicated as high $(\mathrm{H})$, medium $(\mathrm{M})$, or low $(\mathrm{L})$ with an arrow to signify whether the uptake increases $(\uparrow)$ or decreases $(\downarrow)$ with humidity using flue gas-relevant conditions. See Table $S 1$ and corresponding references for further details.

₹ $\mathrm{T}$, temperature.

\section{RESULTS AND DISCUSSION}

Synthesis of MOF-808-AA. MOF-808-AA was obtained through the post-synthetic incorporation of amino acids into MOF-808, for which the formate ligands have been removed to give what is referred to as MOF-808-FR. Typically, microcrystalline MOF-808 was first synthesized, and the formate $\left(\mathrm{HCOO}^{-}\right)$ligands were removed by treatment with hydrochloric acid $(\mathrm{HCl})$ according to reported procedures (Figure 1a). ${ }^{38,44}$ The product was then immersed in a saturated aqueous or dimethyl sulfoxide (DMSO) solution of an amino acid at a given temperature for 3 days (Table 2, SI Section S3), during which exchange of fresh solutions was performed 3 times per day. The solid was then washed with deionized water 3 times per day for 3 days, followed by treatment with $\mathrm{pH} 10$ buffer solutions of the amino acid or a $10 \%$ 1,8-diazabicyclo(5.4.0) undec-7-ene (DBU) solution in tetrahydrofuran for 1 day, and further washed with acetone for an additional day before activation under dynamic vacuum at $140{ }^{\circ} \mathrm{C}$. In this work, 11 amino acids (Figure $1 \mathrm{~b}$ ) were loaded into MOF-808-FR to yield a series of MOF-808-AAs with a general empirical formula of $\left[\mathrm{Zr}_{6} \mathrm{O}_{4}(\mathrm{OH})_{4}(\mathrm{BTC})_{2}(\mathrm{AA})_{N}(\mathrm{OH})_{6-\mathrm{N}}\left(\mathrm{H}_{2} \mathrm{O}\right)_{6-\mathrm{N}}, \mathrm{AA}\right.$ $=$ amino acid anion], where loading number $N$ denotes the molar equivalence of amino acids per $\mathrm{Zr}_{6} \mathrm{O}_{4}(\mathrm{OH})_{4}$ cluster (or secondary building unit, SBU).

For easy reference, the names and abbreviations of the amino acids, and relevant information of the resulting MOF-808-AAs are summarized in Table 2. The composition of the amino acid-loaded MOFs was determined through liquid-state ${ }^{1} \mathrm{H}$ NMR measurements of the MOFs fully hydrolyzed into their components with hydrofluoric acid ( $\mathrm{HF})$ and deuterium chloride $(\mathrm{DCl})$ in a solvent mixture of DMSO- $d_{6}$ and deuterium oxide $\left(\mathrm{D}_{2} \mathrm{O}\right)$ (referred to as "digest NMR", Section S3). To determine the loading of amino acids, the integrations of amino acid signals were compared to that of the BTC linker, thereby giving the ratio between amino acids and the linker. Fourier-transform infrared spectroscopy (FT-IR, SI Section S6), powder X-ray diffraction (PXRD, SI Section S5), scanning electron microscopy (SEM, SI Section S7), as well as $\mathrm{N}_{2}$ and $\mathrm{CO}_{2}$ sorption studies were carried out to further characterize the samples.

Structure of MOF-808-AA. The structure of MOF-808 is composed of the SBUs $\mathrm{Zr}_{6} \mathrm{O}_{4}(\mathrm{OH})_{4}(-\mathrm{COO})_{6}(\mathrm{HCOO})_{6}{ }^{38}$ which are connected to each other through 1,3,5-benzenetricarboxylate linkers, yielding a porous, extended, three-dimensional framework (Figure 1a). Each of the SBUs is comprised of six $\mathrm{ZrO}_{8}$ tetragonal antiprisms linked by sharing tetragonal caps through $\mu_{3}-\mathrm{O}$ atoms. On the periphery of the SBU are a total of 12 exchangeable coordination sites bridging between adjacent $\mathrm{Zr}$ atoms. In the precursor framework, MOF-808, these sites are occupied by formate $\left(\mathrm{HCOO}^{-}\right)$ligands in bidentate or monodentate binding mode, while in MOF808-FR, the sites are most likely occupied by $\mathrm{H}_{2} \mathrm{O}$ and $\mathrm{OH}^{-}$for charge balance (SI Section S3). The loading of amino acids involves binding of their carboxylate $\left(-\mathrm{COO}^{-}\right)$groups to these sites to form the desired derivatives used in this work (Figure 1a). The extended linking of Zr SBUs and BTC linkers form two kind of interconnected pores: small, tetrahedral pores of $1.2 \AA$ in aperture diameter that are inaccessible to guest molecules; and large, adamantane-shaped pores of $18 \AA$ in diameter that are highly interconnected through apertures of $14 \AA$ in diameter. ${ }^{44}$ The installation of amino acid ligands allows the amino groups $\left(-\mathrm{NH}_{2}\right.$ or $\left.-\mathrm{NH}-\right)$ on the alkyl chains to point to the inside of the pores, which serve as the primary sites to interact with, and thus capture $\mathrm{CO}_{2}$ entering the pores from the exterior.

To validate this, single-crystal samples of a representative variant, MOF-808-Gly $\left[\mathrm{Zr}_{6} \mathrm{O}_{4}(\mathrm{OH})_{4}(\mathrm{BTC})_{2}(\mathrm{Gly})_{N}(\mathrm{OH})_{6-\mathrm{N}}\left(\mathrm{H}_{2} \mathrm{O}\right)_{6-\mathrm{N}}\right.$, Gly $\left.=\mathrm{NH}_{2} \mathrm{CH}_{2} \mathrm{COO}^{-}\right]$, were prepared using a similar procedure as for 


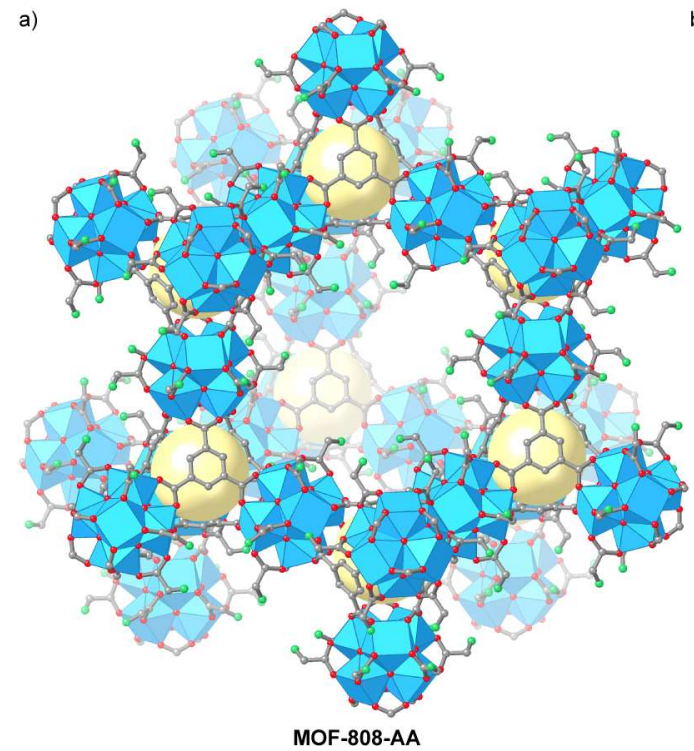

b)

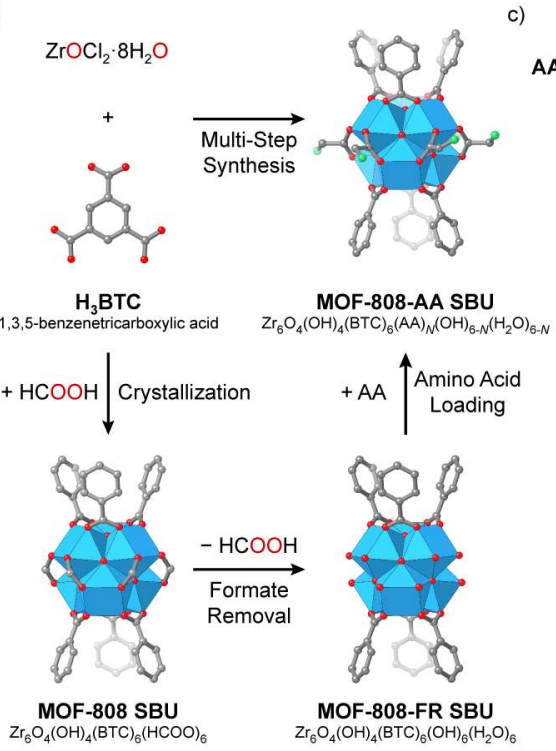

$\mathrm{AA}={\underset{\mathrm{OH}}{\mathrm{Oly}}}_{\mathrm{NH}_{2}}^{\mathrm{O}}$
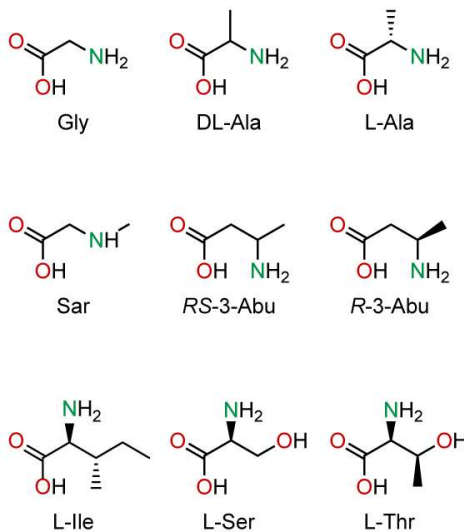

Figure 1. (a) The structure of MOF-808-AA and (b) general synthetic scheme for MOF-808-AA from crystallization of MOF-808 to post-synthetic formate removal and amino acid loading, represented with zoom-in views of the Zr SBUs to highlight the changes of coordination in each step. Structural schemes of the coordinatively loaded amino acids are provided in (c) corresponding to abbreviations in Table 2, respectively. Atomic models of MOF-808-Gly and its SBU with a loading number $\mathrm{N}=6$ are used to represent the general structure of MOF-808-AA. Zr atoms are represented as light blue polyhedra, while other atoms are represented as spheres (Color code: $\mathrm{C}$, gray; $\mathrm{O}$, red; $\mathrm{N}$, green). $\mathrm{H}$ atoms are omitted, and the yellow spheres highlight the small tetrahedral pores for clarity.

Table 2. Summary of Loading and Reaction Conditions of Selected Amino Acids, and $\mathrm{CO}_{2}$ Uptake Capacities of MOF-808-AAs

\begin{tabular}{|c|c|c|c|c|c|c|c|c|}
\hline \multirow[t]{2}{*}{ Amino Acid } & \multirow[t]{2}{*}{ Abbreviation } & \multirow[t]{2}{*}{$\mathrm{pK}_{\mathrm{a}}^{45,46}$} & \multirow{2}{*}{$\begin{array}{l}\text { Loading } \\
(N)\end{array}$} & \multirow{2}{*}{$\begin{array}{c}\text { Temperature } \\
\left({ }^{\circ} \mathrm{C}\right)\end{array}$} & \multirow{2}{*}{\multicolumn{2}{|c|}{$\begin{array}{l}\text { Solvent Amine Loading } \\
\qquad\left(\mathrm{mmol} \mathrm{g}^{-1}\right)\end{array}$}} & \multicolumn{2}{|c|}{ Uptake $\left(\mathrm{mmol} \mathrm{g}^{-1}, 25^{\circ} \mathrm{C}\right)$} \\
\hline & & & & & & & $4 \mathrm{kPa}$ & $15 \mathrm{kPa}$ \\
\hline \multirow[t]{2}{*}{ Glycine } & Gly & 9.60 & 5.89 & 85 & $\mathrm{H}_{2} \mathrm{O}$ & 3.84 & 0.247 & 0.540 \\
\hline & & & & & & & $0.525^{\ddagger}$ & $0.693^{\ddagger}$ \\
\hline Sarcosine & Sar & 10.35 & 1.71 & 85 & $\mathrm{H}_{2} \mathrm{O}$ & 1.23 & 0.239 & 0.561 \\
\hline L-Alanine & L-Ala & 9.69 & 3.55 & 100 & $\mathrm{H}_{2} \mathrm{O}$ & 2.38 & 0.250 & 0.520 \\
\hline DL-Alanine & DL-Ala & 9.69 & 2.98 & 100 & $\mathrm{H}_{2} \mathrm{O}$ & 2.04 & 0.213 & 0.482 \\
\hline (R)-3-Aminobutanoic acid & $R-3-\mathrm{Abu}$ & 10.53 & 2.12 & 85 & $\mathrm{H}_{2} \mathrm{O}^{\diamond}$ & 1.47 & 0.132 & 0.317 \\
\hline$(R S)$-3-Aminobutanoic acid & $R S-3-\mathrm{Abu}$ & 10.53 & 2.10 & 85 & $\mathrm{H}_{2} \mathrm{O}^{\diamond}$ & 1.45 & 0.189 & 0.383 \\
\hline L-Isoleucine & L-Ile & 9.60 & 1.44 & 85 & $\mathrm{H}_{2} \mathrm{O}$ & 1.00 & 0.203 & 0.434 \\
\hline L-Serine & L-Ser & 9.15 & 3.61 & 85 & $\mathrm{H}_{2} \mathrm{O}$ & 2.32 & 0.248 & 0.603 \\
\hline L-Threonine & L-Thr & 9.10 & 4.48 & 100 & $\mathrm{H}_{2} \mathrm{O}$ & 2.67 & 0.119 & 0.320 \\
\hline L-Histidine & L-His & 9.17 & 4.03 & 85 & $\mathrm{H}_{2} \mathrm{O}$ & 2.26 & 0.108 & 0.331 \\
\hline DL-Lysine & DL-Lys & $8.95,10.53$ & 1.87 & 120 & DMSO & 2.48 & 0.705 & 1.040 \\
\hline
\end{tabular}

the microcrystalline samples, with the acetone washing steps specifically avoided to eliminate possible assignment difficulties during the structural refinement. $20-40 \mu \mathrm{m}$-sized single crystals of MOF808 were prepared according to the reported procedure, ${ }^{38}$ which were further treated with $1 \mathrm{~mol} \mathrm{~L}^{-1} \mathrm{HCl}$ solution to remove formate ligands. Glycine was incorporated with retention of morphology and crystallinity of the crystals, which were found suitable for single-crystal X-ray diffraction (SXRD) studies. Fully activated crystals were used for collection of SXRD data with synchrotron radiation at Beamline 12.2.1 of the Advanced Light Source (ALS) at Lawrence Berkeley National Laboratory at $100 \mathrm{~K}$ using a nitrogen cold stream.
The structure of MOF-808-Gly was solved in the cubic space group $F d \overline{3} m$, with the unit cell parameter of $a=35.1413$ (12) A (SI Section S4). The extended backbone of the MOF was well-resolved to show the same structure as in MOF-808, and relatively small thermal displacement parameters, indicating the retention of crystallinity during the post-synthetic modification (Figure S14).

An average of 2.9 glycinate ligands, as determined by the occupancies of the $\alpha-C$ and $\mathrm{N}$ atoms in the SXRD result, were found bound to each $\mathrm{Zr}$ SBU in a bidentate bridging fashion between two $\mathrm{Zr}$ atoms. The amino $\mathrm{N}$ atom was found in significant disorder, which was largely attributed to the free rotation of the $\mathrm{C}-\mathrm{C}$ bond in the 
glycinate ligand, indicating no significant interaction with other parts of the MOF (Figure 2 and Figure S15). The lower loading ( $N$ $=2.9$ ) of glycinate in the single-crystalline samples compared to microcrystalline samples $(N=5.89)$ was likely attributed to the limited diffusion of guest glycine molecules through the crystal during the incorporation reaction. However, since no significant intermolecular interactions have been found among glycinate ligands as observed in the single-crystal structure, we believe it represents the binding and conformation in the bulk, microcrystalline samples.

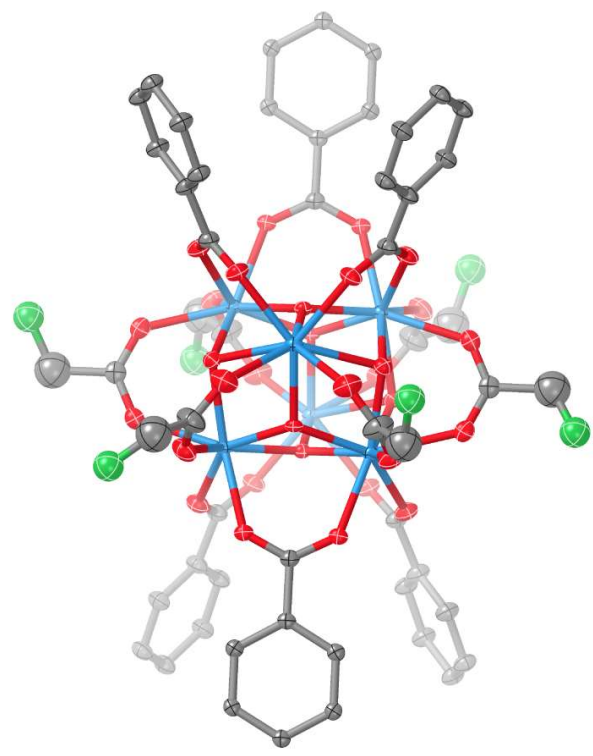

Figure 2. Single-crystal structure of a segment of MOF-808-Gly focused on one $\mathrm{Zr}_{6} \mathrm{SBU}$, highlighting the bridging binding mode of glycinates to adjacent $\mathrm{Zr}$ atoms. Thermal ellipsoids of atoms are shown at 50\% probability level. Color code: C, gray; O, red; N, green; Zr, blue. For clarity, $\mathrm{H}$ atoms, disordered $\mu_{3}-\mathrm{O}$ atoms, and $\mathrm{OH}^{-} / \mathrm{H}_{2} \mathrm{O}$ groups are omitted. One randomly selected conformation among the refined rotationally disordered positions of each $-\mathrm{NH}_{2}$ group is shown to help clarify the spatial arrangement of the amino acid residues in MOF-808-Gly.

For the bulk sample, the retention of crystallinity was first established through PXRD measurements (SI Section S5). The composition was then characterized with FT-IR measurements (SI Section S6). Compared to MOF-808, nearly all formate ligands were absent in MOF-808-FR, as was evidenced by the absence of absorbance bands at $1582 \mathrm{~cm}^{-1}$ and $1337 \mathrm{~cm}^{-1}$ which have been assigned as COO stretches of the formate ligands. ${ }^{47}$ Furthermore, it was determined that $>98.5 \%$ of the formate ligands were removed based on digest NMR results on MOF-808-FR. ${ }^{48,49}$ The incorporation of glycine molecules into MOF-808-FR was first probed by the appearance of FT-IR absorbance bands at $\sim 2960 \mathrm{~cm}^{-1}$ assigned as the C-H stretch of glycinate ligands present in the product MOF-808-Gly. ${ }^{50}$ Representative scanning electron micrographs of MOF-808 and MOF-808-Gly showed that the octahedral microcrystals of the MOF remained unaltered before and after the reactions (Figures S20 and S21). Energy dispersive X-ray spectroscopy (EDX) on a set of randomly sampled microcrystals indicated that no remaining chlorine $(\mathrm{Cl})$ was found after the last step of the coordinative functionalization (Figure S22).
$\mathbf{N}_{2}$ Sorption Isotherm Studies. $\mathrm{N}_{2}$ sorption isotherms were measured for MOF-808, MOF-808-FR, and MOF-808-AAs at $77 \mathrm{~K}$ (Figure 3a, SI Section S8.1) to confirm their permanent porosity. Comparison among MOF-808, MOF-808-FR, and the representative MOF-808-Gly (Figure 3a) showed that the formate removal step increased the porosity, as indicated by the change of the Brunauer-Emmett-Teller (BET) surface area from $1680 \mathrm{~m}^{2} \mathrm{~g}^{-1}$ to $1971 \mathrm{~m}^{2} \mathrm{~g}^{-1}$ (Figures S23 and S24). By contrast, the amino acid loading reaction generally reduced the porosity. This was exemplified by MOF-808-Gly, whose BET surface area was reduced to $1427 \mathrm{~m}^{2} \mathrm{~g}^{-1}$ (Figure S25).

It is likely that besides contributing to the total mass of the MOF, the residues of the amino acids occupy space in the pores, thus considerably reducing the surface area. Evidence from the pore size distribution data (Figures S26-S32) derived from $\mathrm{N}_{2}$ sorption isotherms further indicate that the pore structures were retained in the intermediate and the final products. As expected, the amine ligands were introduced without altering the periodic porous MOF structures. $\mathrm{N}_{2}$ isotherms and BET surface areas of other MOF-808-AAs are given in Figures S33-S41.

Single-Component $\mathrm{CO}_{2}$ Sorption Isotherms. Single-component $\mathrm{CO}_{2}$ adsorption and desorption isotherms were measured at 25 ${ }^{\circ} \mathrm{C}(\sim 298 \mathrm{~K})$ for all obtained MOF-808-AA variants and their precursor frameworks (Figures $3 \mathrm{~b}$ and c, SI Section S8.2.1). Comparison of the isotherms of MOF-808 and MOF-808-FR, MOF-808-Gly show that the latter has increased uptake at carbon capture-relevant pressures (4 $\mathrm{kPa}$ and $15 \mathrm{kPa}$, Table 2 ). In addition, a significant hysteresis is observed between the adsorption branch and desorption branch, characteristic of $\mathrm{CO}_{2}$ chemisorption, which is not fully reversible at $25^{\circ} \mathrm{C}$. This phenomenon was generally observed for other MOF-808-AA variants, while absent for MOF-808 or MOF-808-FR. This eliminates the possibility of having any unoccupied sites (open metal sites) in the MOF backbone contributing to the observed strong adsorption.

Comparison of $\mathrm{CO}_{2}$ isotherms at $25^{\circ} \mathrm{C}$ among the MOF-808-AAs (Figure 3c, Figures $\mathrm{S} 43-\mathrm{S} 53$, Table 2) yielded a range of $\mathrm{CO}_{2}$ uptake performances, varying between $0.092 \mathrm{mmol} \mathrm{g}^{-1}$ and $0.705 \mathrm{mmol} \mathrm{g}^{-1}$ at $4 \mathrm{kPa}\left(4 \% \mathrm{CO}_{2}\right.$ in 1 atm gas mixture, relevant to natural gas combined cycle flue gas capture), and between $0.277 \mathrm{mmol} \mathrm{g}^{-1}$ and 1.040 mmol g ${ }^{-1}$ at $15 \mathrm{kPa}\left(15 \% \mathrm{CO}_{2}\right.$ in $1 \mathrm{~atm}$ gas mixture, relevant to coal flue gas capture).

We found that multiple factors influence the $\mathrm{CO}_{2}$ uptake: total amine loading, $\mathrm{pK}_{\mathrm{a}}$ of the amine species, steric hindrance at the local environment in the pore, as well as proximity of adjacent functional groups. Most significantly, a larger gravimetric amine loading and a higher $\mathrm{pK}_{\mathrm{a}}$ of the loaded amine species are correlated to a higher $\mathrm{CO}_{2}$ uptake. The incorporation of DL-lysine into MOF-808-FR, despite a relatively low amino acid loading number $N$ of 1.87 , yielded a gravimetric amine loading of $2.48 \mathrm{mmol} \mathrm{g}^{-1}$, third highest among the series due to the two-fold amine stoichiometry per amino acid loading. The $\mathrm{pK}_{\mathrm{a}}$ of the $\varepsilon-\mathrm{NH}_{2}$ is 10.53 , highest among the amino species, ensured a high affinity even at a low $\mathrm{CO}_{2}$ pressure. These factors combined resulted in the highest $\mathrm{CO}_{2}$ uptake observed for MOF-808DL-Lys among all the MOF-808-AA sorbents at both $\mathrm{CO}_{2}$ levels of interest.

To quantitatively evaluate the sorbents' affinity for $\mathrm{CO}_{2}$, the isosteric heat of adsorption $\left(Q_{\mathrm{st}}\right)$ was determined by measuring $\mathrm{CO}_{2}$ 
a)

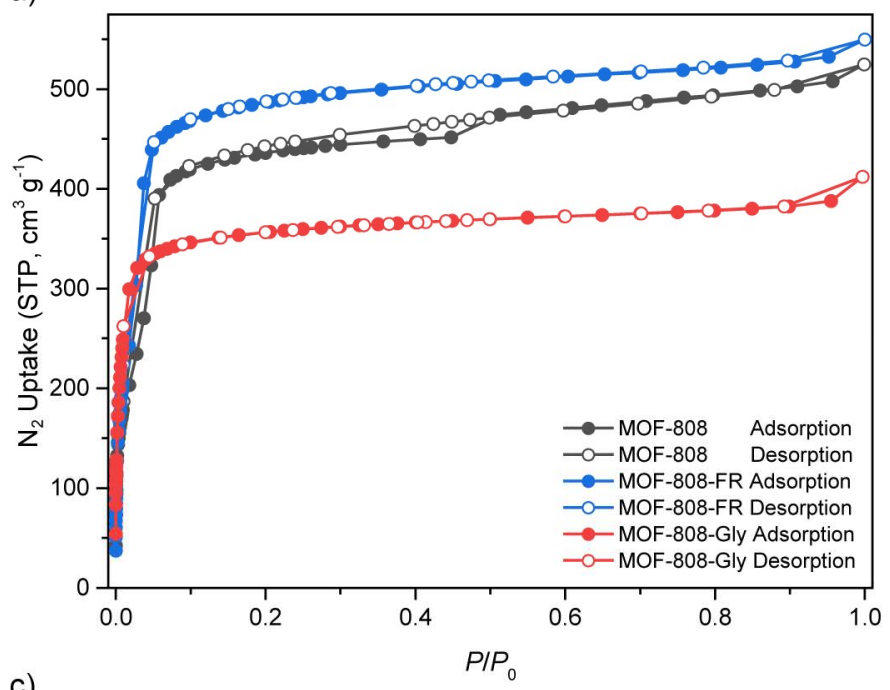

c)

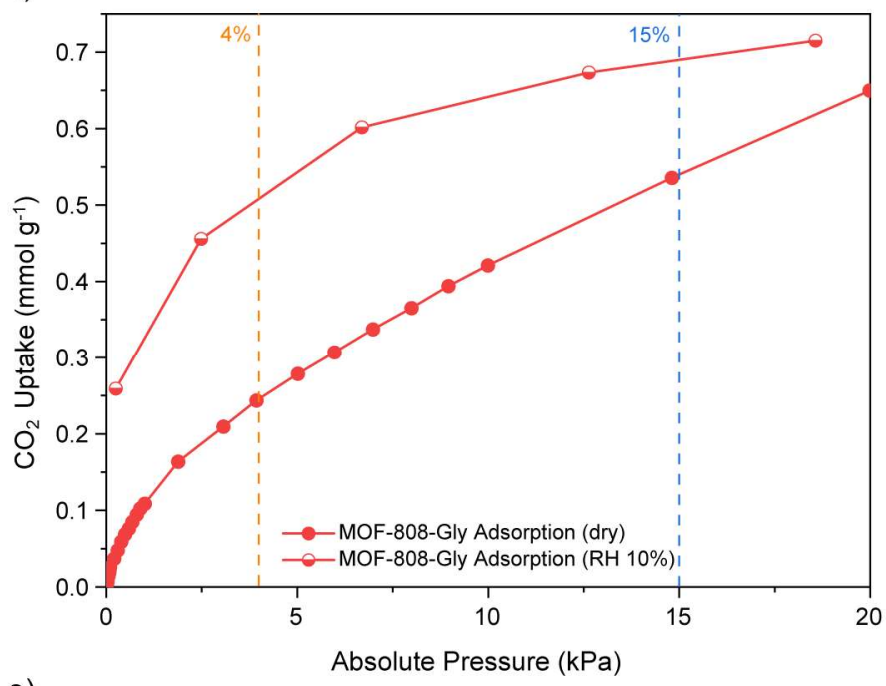

e)

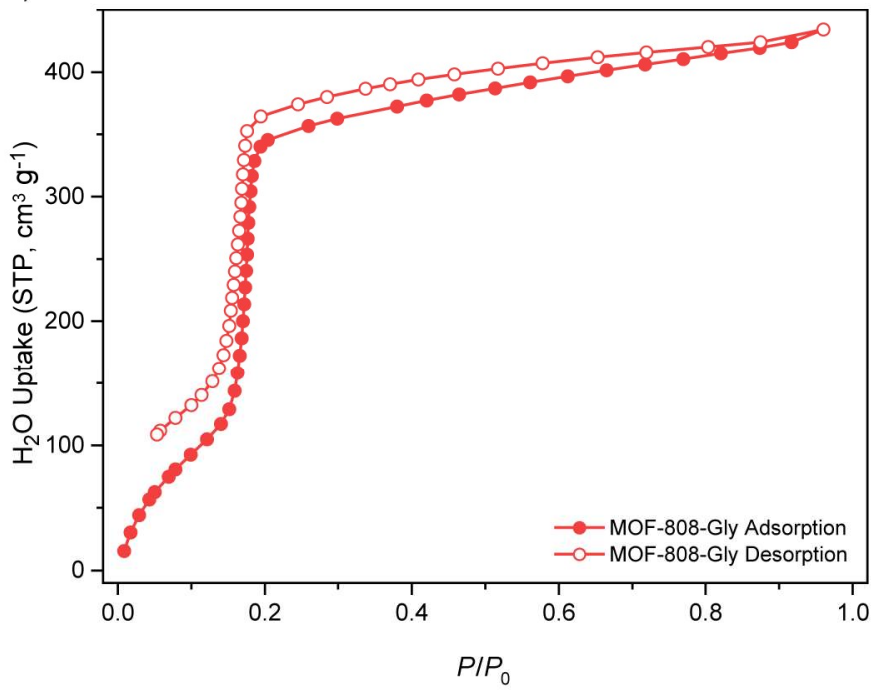

b)

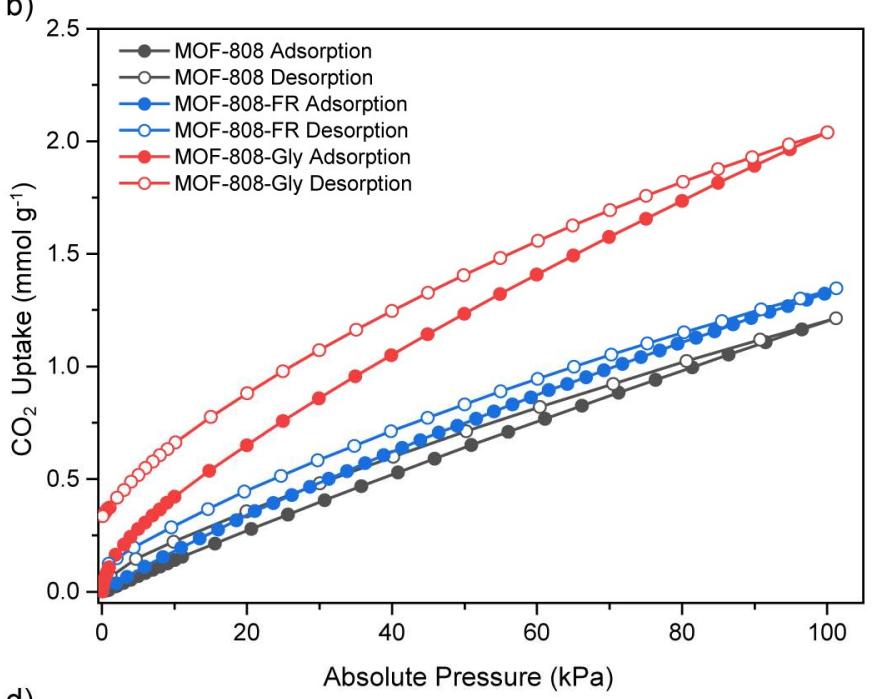

d)

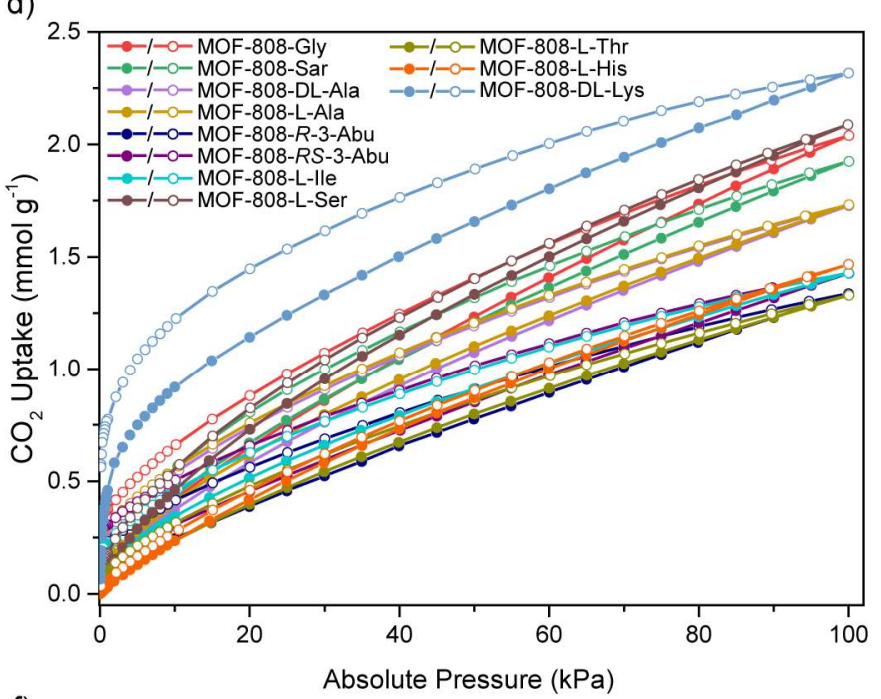

f)

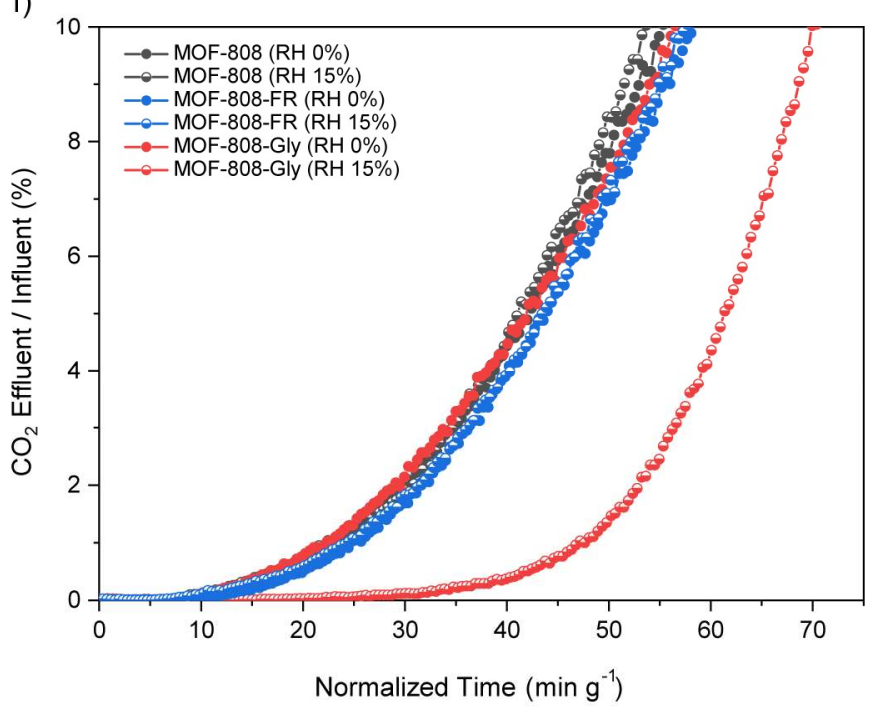

Figure 3. Comparison of (a) $\mathrm{N}_{2}$ sorption isotherms measured at $77 \mathrm{~K}$ and (b) $\mathrm{CO}_{2}$ sorption isotherms measured at $25^{\circ} \mathrm{C}$ for $\mathrm{MOF}-808$, $\mathrm{MOF}-808$ FR, and representative MOF-808-Gly to show the pore geometry and $\mathrm{CO}_{2}$ uptake change before and after post-synthetic modification reactions; (c) overlay of single-component $\mathrm{CO}_{2}$ isotherms of the MOF-808-AA variants, $(\mathrm{d})$ overlay of $\mathrm{CO}_{2} / \mathrm{H}_{2} \mathrm{O}$ binary adsorption isotherm with dry CO $\mathrm{C}_{2}$ isotherm at $25^{\circ} \mathrm{C}$, (e) water sorption isotherm of MOF-808-Gly measured at $25^{\circ} \mathrm{C}$; (f) dynamic $\mathrm{CO}_{2}$ breakthrough curve comparison among MOF-808, MOF808-FR, and MOF-808-Gly in dry and humid ( $\mathrm{RH} 15 \%)$ conditions at $25^{\circ} \mathrm{C}$. 

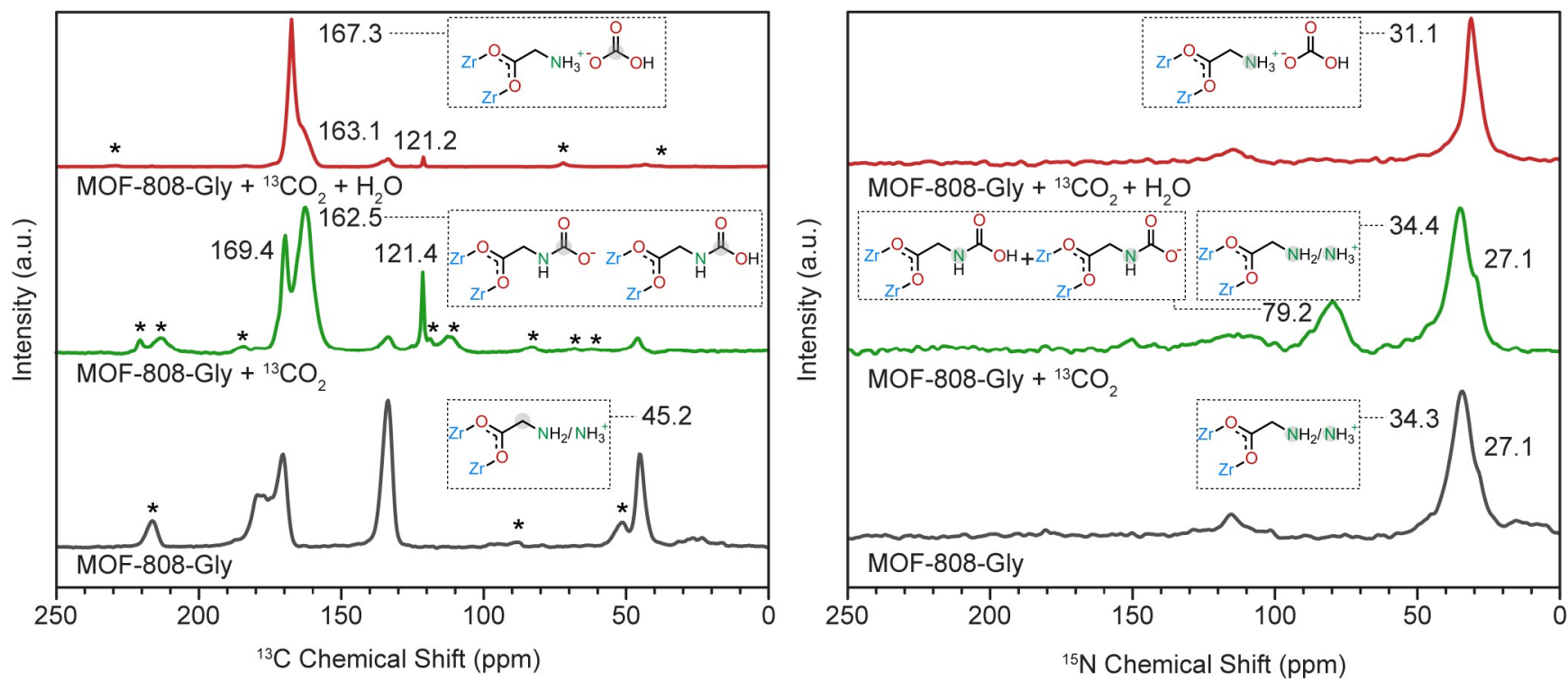

Figure 4. Stacked plots of solid-state ${ }^{13} \mathrm{C}$ (left) and ${ }^{15} \mathrm{~N}$ (right) CP-MAS ssNMR spectra of ${ }^{15} \mathrm{~N}$-labeled MOF-808-Gly before and after adsorption of ${ }^{13} \mathrm{CO}_{2}$ with or without the presence of water. In dark gray (bottom) are the spectra for MOF-808-Gly fully activated under dynamic vacuum. In green (middle) are the spectra for MOF-808-Gly after exposure to $98.7 \mathrm{kPa}{ }^{13} \mathrm{CO}_{2}$ for $24 \mathrm{~h}$. In red (top) are the spectra for MOF-808-Gly after exposure to a $\mathrm{N}_{2}$ atmosphere with $95 \%$ relative humidity at $25^{\circ} \mathrm{C}$ for $24 \mathrm{~h}$, followed by $90.0 \mathrm{kPa}{ }^{13} \mathrm{CO}_{2}$ for $24 \mathrm{~h}$. Signals of interest are marked with their ${ }^{13} \mathrm{C}$ or ${ }^{15} \mathrm{~N}$ chemical shifts and the assignments of major species identified are shown in dashed boxes. Spinning sidebands are marked with “*”.

sorption isotherms at $15^{\circ} \mathrm{C}(\sim 288 \mathrm{~K}), 25^{\circ} \mathrm{C}$, and $35^{\circ} \mathrm{C}(\sim 308 \mathrm{~K})$ for selected MOF samples (SI Section S8.2.2). The $Q_{\text {st }}$ value of MOF-808-DL-Lys at zero loading was estimated as $\sim 80 \mathrm{~kJ} \mathrm{~mol}^{-1}$ (Figures S56 and S57). This is significantly higher when compared to $\sim 46 \mathrm{~kJ} \mathrm{~mol}^{-1}$ of MOF-808-Gly (Figures S54 and S55), of which the $\alpha-\mathrm{NH}_{2}$ were from glycine, having a comparatively lower $\mathrm{pK}_{\mathrm{a}}$ value of 9.60. This observation further supports the proposed relationship between higher $\mathrm{pK}_{\mathrm{a}}$ of the amine species and stronger $\mathrm{CO}_{2}$ binding in relatively low $\mathrm{CO}_{2}$ pressure among the MOF-808-AA series.

Binary $\mathrm{CO}_{2} / \mathrm{H}_{2} \mathrm{O}$ Adsorption Isotherms and Dynamic Breakthrough Experiments. As moisture is unavoidable toward achieving low-cost, practical flue gas capture, studying the influence of water on the sorbent's $\mathrm{CO}_{2}$ uptake is important. To probe this, we measured the binary $\mathrm{CO}_{2} / \mathrm{H}_{2} \mathrm{O}$ adsorption isotherm of the representative MOF-808-Gly. The experiment was carried out in a custom-built volumetric system (SI Section S8.3.1). ${ }^{51}$ The sample was first fully regenerated in situ under vacuum at $150{ }^{\circ} \mathrm{C}$. Water was injected to achieve a headspace relative humidity of $\sim 10 \%(3.6 \mathrm{mmol}$ $\mathrm{g}^{-1}$, Figure $3 \mathrm{~d}$ and e), and then $\mathrm{CO}_{2}$ was loaded on the water-loaded sorbent. The loadings of both $\mathrm{CO}_{2}$ and $\mathrm{H}_{2} \mathrm{O}$ were monitored with a gas chromatograph (GC) and the loadings of each species were determined via a mass balance. The Toth model ${ }^{52}$ was applied to fit the binary isotherm to extract the uptake at the given $\mathrm{CO}_{2}$ pressures (Table 2, SI Section S8.3.2).

The resulting isotherm revealed a significant increase of $\mathrm{CO}_{2}$ uptake of MOF-808-Gly in the presence of water compared to dry conditions. Specifically, overlay of the binary $\mathrm{CO}_{2} / \mathrm{H}_{2} \mathrm{O}$ and single-component $\mathrm{CO}_{2}$ sorption isotherms of MOF-808-Gly indicated a more than two-fold increase in $\mathrm{CO}_{2}$ uptake at $4 \mathrm{kPa}$, which continued to be above the dry isotherm until $\sim 20 \mathrm{kPa}$ (Figure $3 \mathrm{~d}$ ).

The increased uptake in the presence of water was further studied in a dynamic manner with a breakthrough system (SI Section S9):
MOF samples were loaded in a packed bed and a stream of $\mathrm{CO}_{2^{-}}$ containing gas mixture was passed through the sorbent and analyzed by GC. Normalized breakthrough curves of MOF-808, MOF-808FR, and MOF-808-Gly are overlaid to compare the behavior of the sorbents with or without humidity ( $\mathrm{RH} 15 \%, 25^{\circ} \mathrm{C}$, Figure $\left.3 \mathrm{f}\right)$. Both MOF-808 and MOF-808-FR exhibited no significant change or a slightly earlier breakthrough time upon humidification of the stream. In contrast, MOF-808-Gly exhibited a significant delay of the breakthrough, corresponding to an increased uptake in the presence of humidity. This is in line with the increased uptake observed in the binary adsorption isotherm study.

These observations combined support the sorbent's characteristics of humidity-enhanced $\mathrm{CO}_{2}$ uptake performance in such scenarios. This is being attributed to the sorption mechanism of MOF-808AAs, achieved by the introduction of amino acids as presented in the next section.

Mechanistic Studies of $\mathrm{CO}_{2}$ Chemisorption Using SolidState NMR. To understand the mechanism of the $\mathrm{CO}_{2}$ adsorption chemistry of MOF-808-AAs in the presence of water, solid-state cross-polarization magic-angle spinning (CP-MAS) ${ }^{13} \mathrm{C}$ and ${ }^{15} \mathrm{~N}$ NMR experiments were conducted on the representative variant MOF-808-Gly to probe the change of chemical species before and after loading of ${ }^{13} \mathrm{CO}_{2}$, with and without the presence of water (Figure 4, SI Section S10). ${ }^{15} \mathrm{~N}$-labeled glycine was used for the preparation of ${ }^{15} \mathrm{~N}$-labeled MOF-808-Gly following the same synthetic and activation procedure. ${ }^{13} \mathrm{C}$ and ${ }^{15} \mathrm{~N}$ CP-MAS solid-state NMR (ssNMR) experiments were performed on the resulting sample to establish the composition of the pristine MOF sorbent (Figure 4, bottom). Signals at $\delta{ }^{13} \mathrm{C}=170.3$ and $133.6 \mathrm{ppm}$ were attributed to the carboxylate and aromatic carbons of the BTC linker, respectively. Glycine ligand signals were found with chemical shifts of $\delta^{13} \mathrm{C}$ $=179.5$ and $45.2 \mathrm{ppm}$, attributed to the carboxylate and $\alpha$-carbons, respectively. ${ }^{15} \mathrm{~N}$ labeling of the $\alpha$-amino $\mathrm{N}$ of the glycinate ligand 
allowed tracking any changes in its chemical environment, which is key to understanding the chemical nature of the sorption phenomenon. The signals at $\delta{ }^{15} \mathrm{~N}=34.3$ and $27.1 \mathrm{ppm}$ are assigned to the amino groups in the protonated and deprotonated states.

The ${ }^{15} \mathrm{~N}$-labeled MOF-808-Gly sample was kept in the same rotor and dosed with $98.7 \mathrm{kPa}{ }^{13} \mathrm{CO}_{2}$ at $25^{\circ} \mathrm{C}$, followed by repeating the CP-MAS ssNMR measurement. In the resulting spectra, signals appearing at $\delta{ }^{13} \mathrm{C}=169.4$ and $162.5 \mathrm{ppm}$ indicates the formation of carbamic acid $(-\mathrm{NHCOOH})$ and carbamate $\left(-\mathrm{NHCOO}^{-}\right)$species, along with free $\mathrm{CO}_{2}$ at $\delta{ }^{13} \mathrm{C}=121.4 \mathrm{ppm}$. This is further confirmed by the emerging signal at ${ }^{15} \mathrm{~N}=79.2 \mathrm{ppm}$ in the ${ }^{15} \mathrm{~N}$ ssNMR spectrum, while the presence of signals at $\delta^{15} \mathrm{~N}=34.4$ and $27.1 \mathrm{ppm}$ indicate the presence of ammonium species as the counterions of the carbamate as well as unreacted $\alpha$-amines.

For comparison, a fully activated, ${ }^{15} \mathrm{~N}$-labeled MOF-808-Gly sample was humidified through exposure to $95 \%$ relative humidity in a $\mathrm{N}_{2}$ atmosphere at $1 \mathrm{~atm}$ at $25^{\circ} \mathrm{C}$ for $24 \mathrm{~h}$. This was followed by exposure to $90.0 \mathrm{kPa}{ }^{13} \mathrm{CO}_{2}$ for $24 \mathrm{~h}$ prior to CP-MAS ssNMR measurements under the same conditions as the dry sample. The resulting ${ }^{13} \mathrm{C}$ NMR spectrum showed that the predominant species exhibited a new signal at $\delta{ }^{13} \mathrm{C}=167.3 \mathrm{ppm}$, which was assigned to ammonium bicarbonate $\left(-\mathrm{NH}_{3}{ }^{+} \mathrm{OCO}_{2} \mathrm{H}\right)$ species. This was accompanied by a shoulder peak observed at $\delta{ }^{13} \mathrm{C}=163.1 \mathrm{ppm}$, likely indicating small amounts of carbamates and carbamic acids. However, their ${ }^{15} \mathrm{~N}$ ssNMR signals expected around $\delta{ }^{15} \mathrm{~N}=79.2 \mathrm{ppm}$ were not observed, possibly due to their low population. A single peak was found at $\delta{ }^{15} \mathrm{~N}=31.1 \mathrm{ppm}$ predominant in the spectrum, which can be attributed to protonated $\alpha$-ammonium in the glycinate ligands. We thus conclude that the predominant chemisorption product is ammonium bicarbonate.

To further probe the speciation of the sorption process, activation treatment at ambient and elevated temperature was applied to the samples dosed with ${ }^{13} \mathrm{CO}_{2}$ under dry and humid conditions. ${ }^{15} \mathrm{~N}-\mathrm{la}$ beled MOF-808-Gly dosed with ${ }^{13} \mathrm{CO}_{2}$ in a dry condition was kept in the same rotor and evacuated under dynamic vacuum at room temperature $\left(\sim 25^{\circ} \mathrm{C}\right)$ for $48 \mathrm{~h}$, followed by measurements of $\mathrm{CP}$ MAS ssNMR under the same conditions (Figure S62). Absence of signals around ${ }^{13} \mathrm{C}=121.4 \mathrm{ppm}$, where free or physisorptive ${ }^{13} \mathrm{CO}_{2}$ was expected, indicated the removal of ${ }^{13} \mathrm{CO}_{2}$ in the rotor headspace being physisorbed in the MOF. Additionally, we observed relative attenuation of the signals at $\delta{ }^{13} \mathrm{C}=169.4$ and $162.5 \mathrm{ppm}$ which we attributed to carbamic acid or carbamate species. Similarly, the signal at $\delta{ }^{15} \mathrm{~N}=79.2 \mathrm{ppm}$ in the ${ }^{15} \mathrm{~N}$ NMR spectrum was still present, indicating the retention of carbamic acid and carbamate species. This observation was in accordance with the non-zero uptake at very low pressures in the desorption branch of the single-component $\mathrm{CO}_{2}$ isotherm of MOF-808-Gly, and similar phenomena in other MOF-808-AA variants. In a further step, the same sample $\left({ }^{15} \mathrm{~N}-\mathrm{la}-\right.$ beled MOF-808-Gly, ${ }^{13} \mathrm{CO}_{2}$ dosed, activated at room temperature) was reactivated under dynamic vacuum while heated to $120^{\circ} \mathrm{C}$ for $24 \mathrm{~h}$ (Figure S62). The resulting ${ }^{13} \mathrm{C}$ and ${ }^{15} \mathrm{~N}$ NMR spectra largely resembled the ones measured on pristine ${ }^{15} \mathrm{~N}$-labeled MOF-808-Gly prior to exposure to $\mathrm{CO}_{2}$, confirming the requirement of heating to fully regenerate MOF-808-Gly from carbamate or carbamic acid sorption products.

By contrast, vacuum regeneration of ${ }^{15} \mathrm{~N}$-labeled MOF-808-Gly that was loaded with ${ }^{13} \mathrm{CO}_{2}$ under a humid condition exhibited considerable bicarbonate removal at ambient temperature (Figure S63), as evidenced by significant attenuation of signals in ssNMR spectra from around $\delta{ }^{13} \mathrm{C}=167.3 \mathrm{ppm}$ (bicarbonate) to a set of peaks at $\delta^{13} \mathrm{C}=168.0,165.6$, and $162.0 \mathrm{ppm}$. In addition, emerging signals at $\delta{ }^{13} \mathrm{~N}=82.8 \mathrm{ppm}$ further supported that part of the bicarbonate species transformed into carbamate and carbamic acid species during the vacuum regeneration process.

Based on these observations, we propose the overall mechanistic process of $\mathrm{CO}_{2}$ chemisorption in MOF-808-AAs as summarized in Scheme 1: (1) in dry conditions, $\mathrm{CO}_{2}$ reacts with amino groups to form carbamates or carbamic acids (1-2 amines to $1 \mathrm{CO}_{2}$ ) which necessarily require heat for regeneration; (2) in humid conditions, $\mathrm{CO}_{2}$ reacts with amino groups to form carbamates or carbamic acids (1-2 amines to $1 \mathrm{CO}_{2}$ ) with a higher affinity at low $\mathrm{CO}_{2}$ pressures; ${ }^{20}$ (3) in humid conditions, where abundant $\mathrm{CO}_{2}$ is present, $\mathrm{CO}_{2}$ reacts with amino groups to form mostly bicarbonates (net $\sim 1$ amine to 1 $\mathrm{CO}_{2}$ ) with a likely equilibrium with carbamic acids and carbamates, ${ }^{32,53}$ which can be reversed through vacuum regeneration at ambient temperature. We thus hypothesized that the increased stoichiometry of the bicarbonate species formation in abundant $\mathrm{CO}_{2}$ and humid conditions partly accounts for the enhanced capture performance of MOF-808-AA sorbents. More importantly, we envisioned that their facile vacuum regeneratability should enable capturing $\mathrm{CO}_{2}$ through vacuum swing adsorption under ambient conditions.

Scheme 1. Proposed Chemisorption Mechanism of $\mathrm{CO}_{2} \mathrm{Uptake}$ in MOF-808-AAs with (Humid) and without (Dry) the Presence of Water

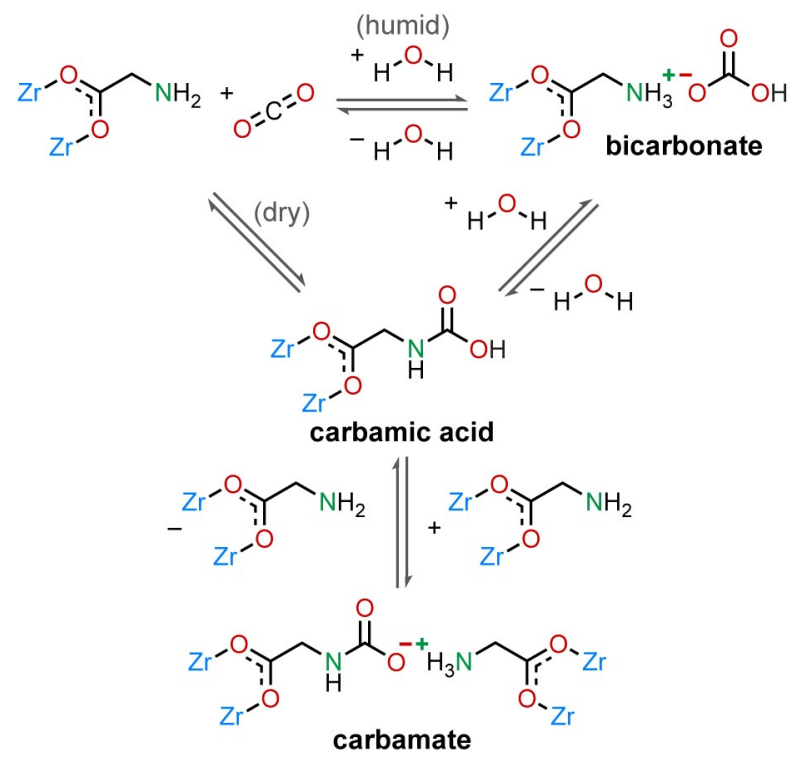

Vacuum Swing Adsorption Capture of $\mathrm{CO}_{2}$ from Simulated Coal Flue Gas. In light of the discoveries above, we were encouraged to probe the practicality of applying MOF-808-AA sorbents in VSA cyclic capture scenarios. Particularly, we expected to utilize the formation of bicarbonate in humid coal flue gas conditions to allow for efficient $\mathrm{CO}_{2}$ capture while regenerating using vacuum, a low-energy driving force, at ambient temperature. To examine this, the dynamic capture of $\mathrm{CO}_{2}$ was implemented in an orthogonal packedbed vacuum swing adsorption setup (detailed in SI Section S11). Cylindrical pellets $(6 \mathrm{~mm}$ diameter $\times 5 \mathrm{~mm}$ height $)$ were produced 
through pelletization of pure microcrystalline MOF-808-Gly with a packing density of $0.45 \mathrm{~g} \mathrm{~cm}^{-3}$. Such pellets, weighing $9 \mathrm{~g}$ in total, were activated and loaded into a cylindrical sorption bed $(35 \mathrm{~mm}$ diameter). A simulated coal flue gas composed of $15 \% \mathrm{CO}_{2}(\mathrm{RH}$ $20 \%$ ) balanced with $\mathrm{N}_{2}$ was passed through at $1 \mathrm{~atm}, 20-23^{\circ} \mathrm{C}$, and

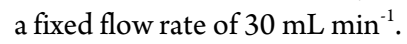

The adsorption-regeneration process was measured in a cyclic manner. The $\mathrm{CO}_{2}$ concentration was monitored at the effluent of the sorption bed, and a threshold of $2 \%$ was set to switch to vacuum regeneration, which was set for a fixed time. For a typical cycle, the adsorption step lasted $5.9 \mathrm{~min}$, when $6.1 \mathrm{~min}$ of vacuum regeneration ( $\sim 10$ Torr) was applied to remove the adsorbed $\mathrm{CO}_{2}$ and $\mathrm{H}_{2} \mathrm{O}$, which were collected at the exhaust. The cyclic dynamic capture capacity was measured by numerical integration of the effluent $\mathrm{CO}_{2}$ pressure as $0.42 \mathrm{mmol} \mathrm{g}^{-1} \mathrm{~h}^{-1}$, and a continuous monitoring of $80 \mathrm{cy}$ cles showed no decay in uptake capacity indicated by the downstream $\mathrm{CO}_{2}$ concentration profile (Figure S67) and calculated $\mathrm{CO}_{2}$ uptake capacity per cycle (Figure S68).

\section{CONCLUSIONS}

We showed in this work that MOF-808, when functionalized with amino acids where their carboxylate is bound directly to the $\mathrm{Zr}(\mathrm{IV})$, produce pores capable of selectively binding $\mathrm{CO}_{2}$ from flue gas. The amine residues of the amino acid units point to the interior of the pores of the MOF, making them of sufficient affinity for $\mathrm{CO}_{2}$ to allow the formation of bicarbonate, along with carbamate and carbamic acid. This $\mathrm{CO}_{2}$ chemistry also allows for the $\mathrm{CO}_{2}$ to be desorbed without heating. Based on this work, it is clear that creating the right environment in the pores of MOFs for maximization of $\mathrm{CO}_{2}$ in the form of bicarbonate would contribute greatly to making energy-efficient carbon dioxide adsorption-desorption cycle.

\section{ASSOCIATED CONTENT}

\section{Supporting Information}

The Supporting Information is available free of charge on the ACS Publications website.

Detailed experimental procedures and data for reported compounds, supplementary figures and tables for characterization, and description of instrumental setups (PDF)

Crystal structure of MOF-808-Gly (CIF)

\section{AUTHOR INFORMATION}

\section{Corresponding Author}

Omar M. Yaghi - Department of Chemistry and Kavli Energy Nanoscience Institute, University of California, Berkeley, Berkeley, California, 94720, United States; orcid.org/0000-0002-5611-3325; Email:yaghi@berkeley.edu

\section{Authors}

Hao Lyu - Department of Chemistry and Kavli Energy Nanoscience Institute, University of California, Berkeley, Berkeley, California 94720, United States; orcid.org/0000-0001-7393-2456
Oscar Iu-Fan Chen - Department of Chemistry and Kavli Energy Nanoscience Institute, University of California, Berkeley, Berkeley, California 94720, United States; orcid.org/0000-0003-4361-0768

Nikita Hanikel — Department of Chemistry and Kavli Energy Nanoscience Institute, University of California, Berkeley, Berkeley, California 94720, United States; orcid.org/0000-0002-3292-5070

Mohammad I. Hossain - Department of Chemical \& Biomolecular Engineering, University of South Alabama, Mobile, Alabama 36688, United States; ORCID: orcid.org/0000-0003-0315-709X

Robinson W. Flaig — Department of Chemistry and Kavli Energy Nanoscience Institute, University of California, Berkeley, Berkeley, California 94720, United States; orcid.org/0000-0003-3090-4724

Xiaokun Pei - Department of Chemistry and Kavli Energy Nanoscience Institute, University of California, Berkeley, Berkeley, California 94720, United States; orcid.org/0000-0002-6074-1463

Ameer Amin - Department of Chemistry and Kavli Energy Nanoscience Institute, University of California, Berkeley, Berkeley, California 94720, United States

Mark D. Doherty - GE Global Research, 1 Research Circle, Niskayuna, New York 12309, United States; orcid.org/0000-00033090-4724

Rebekah K. Impastato - Department of Chemical \& Biomolecular Engineering, University of South Alabama, Mobile, Alabama 36688, United States

T. Grant Glover - Department of Chemical \& Biomolecular Engineering, University of South Alabama, Mobile, Alabama 36688, United States; orcid.org/0000-0002-3393-6038

David R. Moore - GE Global Research, 1 Research Circle, Niskayuna, New York 12309, United States

\section{Author Contributions}

The manuscript was written through contributions of all authors. All authors have given approval to the final version of the manuscript.

\section{Notes}

Crystallographic data of MOF-808-Gly are also available from the Cambridge Crystallographic Data Centre under the reference number CCDC 2118566.

This report was prepared as an account of work sponsored by an agency of the United States Government. Neither the United States Government nor any agency thereof, nor any of their employees, makes any warranty, express or implied, or assumes any legal liability or responsibility for the accuracy, completeness, or usefulness of any information, apparatus, product, or process disclosed, or represents that its use would not infringe privately owned rights. Reference herein to any specific commercial product, process, or service by trade name, trademark, manufacturer, or otherwise does not necessarily constitute or imply its endorsement, recommendation, or favoring by the United States Government or any agency thereof. The views and opinions of authors expressed herein do not necessarily state or reflect those of the United States Government or any agency thereof.

\section{ACKNOWLEDGMENT}

The synthesis, structure, and $\mathrm{CO}_{2}$ uptake isotherms of MOF-808-AA compounds are supported by the Department of Energy under Award Number DE-FE0031956. We thank Dr. Ayan Zhumekenov and Dr. Zhe Ji for their help with materials synthesis, and Dr. Hasan Celik for his support with solid-state NMR measurements. We thank Dr. Eugene A. Kapustin and Mr. Wentao Xu for helpful discussion regarding sorbent synthesis, Dr. Vitali Lissianski and his colleagues at GE Research for insightful discussions concerning materials characterization, and King Abdulaziz City for Science and Technology (KACST) for collaborations. 
O. I.-F. C. acknowledges financial support from the Taiwan Ministry of Education. N. H. acknowledges the receipt of the Kavli ENSI Philomathia Graduate Student Fellowship and thanks the Studienstiftung des deutschen Volkes. T. G. G, M. I. H, and R. K. I. acknowledge financial support from the NASA Cooperative Agreement Notice NNH16ZHA001C Experimental Program to Stimulate Competitive Research under contract NNX16AT47A and the Alabama Space Grant Consortium Fellowship Program. This research used resources of Beamline 12.2.1 of the Advanced Light Source, a U.S. DOE Office of Science User Facility under contract no. DE-AC02-05CH11231. The NMR facility in the College of Chemistry at UC Berkeley is supported in part by NIH S10OD024998.

\section{REFERENCES}

(1) Bui, M.; Adjiman, C. S.; Bardow, A.; Anthony, E.J.; Boston, A.; Brown, S.; Fennell, P. S.; Fuss, S.; Galindo, A.; Hackett, L. A.; Hallett, J. P.; Herzog, H. J.; Jackson, G.; Kemper, J.; Krevor, S.; Maitland, G. C.; Matuszewski, M.; Metcalfe, I. S.; Petit, C.; Puxty, G.; Reimer, J.; Reiner, D. M.; Rubin, E. S.; Scott, S. A.; Shah, N.; Smit, B.; Trusler, J. P. M.; Webley, P.; Wilcox, J.; Mac Dowell, N. Carbon Capture and Storage (CCS): The Way Forward. Energy Environ. Sci. 2018, 11 (5), 1062-1176. https://doi.org/10.1039/C7EE02342A.

(2) DOE/NETL Capture Program R\&D: Compendium of Carbon Capture Technology; U.S. Department of Energy; National Energy Technology Laboratory, 2020.

(3) Fisher, K. S.; Beitler, C.; Rueter, C.; Searcy, K.; Rochelle, G.; Jassim, $\mathrm{M}$. Integrating MEA Regeneration with $\mathrm{CO}_{2}$ Compression and Peaking to Reduce $\mathrm{CO}_{2}$ Capture Costs; DOE/ER/84111; Trimeric Corporation, 2005. https://doi.org/10.2172/842857.

(4) Rochelle, G. T. Amine Scrubbing for $\mathrm{CO}_{2}$ Capture. Science 2009, 325 (5948), 1652-1654. https://doi.org/10.1126/science.1176731.

(5) Knudsen, J. N.; Jensen, J. N.; Vilhelmsen, P.-J.; Biede, O. Experience with CO2 Capture from Coal Flue Gas in Pilot-Scale: Testing of Different Amine Solvents. Energy Procedia 2009, 1 (1), 783-790. https:// doi.org/10.1016/j.egypro.2009.01.104.

(6) Ramezani, R.; Mazinani, S.; Felice, R. D. State-of-the-Art of $\mathrm{CO}_{2}$ Capture with Amino Acid Salt Solutions. Rev. Chem. Eng. 2020. https:// doi.org/10.1515/revce-2020-0012.

(7) Samanta, A.; Zhao, A.; Shimizu, G. K. H.; Sarkar, P.; Gupta, R. PostCombustion $\mathrm{CO}_{2}$ Capture Using Solid Sorbents: A Review. Ind. Eng. Chem. Res. 2012, 51 (4), 1438-1463. https://doi.org/10.1021/ie200 686q.

(8) Wang, Q.; Luo, J.; Zhong, Z.; Borgna, A. $\mathrm{CO}_{2}$ Capture by Solid Adsorbents and Their Applications: Current Status and New Trends. Energy Environ. Sci. 2010, 4 (1), 42-55. https://doi.org/10.1039/C0EE000 64G.

(9) Wang, J.; Huang, L.; Yang, R.; Zhang, Z.; Wu, J.; Gao, Y.; Wang, Q.; O'Hare, D.; Zhong, Z. Recent Advances in Solid Sorbents for $\mathrm{CO}_{2}$ Capture and New Development Trends. Energy Environ. Sci. 2014, 7 (11), 3478-3518. https://doi.org/10.1039/C4EE01647E.

(10) Raganati, F.; Miccio, F.; Ammendola, P. Adsorption of Carbon Dioxide for Post-Combustion Capture: A Review. Energy Fuels 2021, 35 (16), 12845-12868. https://doi.org/10.1021/acs.energyfuels.1c016 18.

(11) Lozinska, M. M.; Mangano, E.; Mowat,J. P. S.; Shepherd, A. M.; Howe, R. F.; Thompson, S. P.; Parker, J. E.; Brandani, S.; Wright, P. A. Understanding Carbon Dioxide Adsorption on Univalent Cation Forms of the Flexible Zeolite Rho at Conditions Relevant to Carbon Capture from Flue Gases. J. Am. Chem. Soc. 2012, 134 (42), 17628-17642. https://doi.org/10.1021/ja3070864.

(12) Xu, X.; Song, C.; Andresen, J. M.; Miller, B. G.; Scaroni, A. W. Novel Polyethylenimine-Modified Mesoporous Molecular Sieve of MCM-41 Type as High-Capacity Adsorbent for $\mathrm{CO}_{2}$ Capture. Energy Fuels 2002, 16 (6), 1463-1469. https://doi.org/10.1021/ef020058u.
(13) Wurzbacher, J. A.; Gebald, C.; Steinfeld, A. Separation of CO2 from Air by Temperature-Vacuum Swing Adsorption Using Diamine-Functionalized Silica Gel. Energy Environ. Sci. 2011, 4 (9), 3584. https://doi.org/10.1039/c1ee01681d.

(14) Choi, W.; Min, K.; Kim, C.; Ko, Y. S.; Jeon, J. W.; Seo, H.; Park, Y.-K.; Choi, M. Epoxide-Functionalization of Polyethyleneimine for Synthesis of Stable Carbon Dioxide Adsorbent in Temperature Swing Adsorption. Nat. Commun. 2016, 7 (1), 12640. https://doi.org/10.10 38/ncomms 12640 .

(15) Krishnamurthy, S.; Boon, J.; Grande, C.; Lind, A.; Blom, R.; de Boer, R.; Willemsen, H.; de Scheemaker, G. Screening Supported Amine Sorbents in the Context of Post-Combustion Carbon Capture by Vacuum Swing Adsorption. Chem. Ing. Tech. 2021, 93 (6), 929-940. https://doi.org/10.1002/cite.202000172.

(16) Alesi, W. R.; Kitchin, J. R. Evaluation of a Primary Amine-Functionalized Ion-Exchange Resin for $\mathrm{CO}_{2}$ Capture. Ind. Eng. Chem. Res. 2012, 51 (19), 6907-6915. https://doi.org/10.1021/ie300452c.

(17) Veneman, R.; Frigka, N.; Zhao, W.; Li, Z.; Kersten, S.; Brilman, W. Adsorption of $\mathrm{H}_{2} \mathrm{O}$ and $\mathrm{CO}_{2}$ on Supported Amine Sorbents. Int.J. Greenh. Gas Control 2015, 41, 268-275. https://doi.org/10.1016/j.ijggc. 2015.07.014.

(18) Zeng, Y.; Zou, R.; Zhao, Y. Covalent Organic Frameworks for $\mathrm{CO}_{2}$ Capture. Adv. Mater. 2016, 28 (15), 2855-2873. https://doi.org/ 10.1002/adma.201505004.

(19) Ding, M.; Flaig, R. W.; Jiang, H. L.; Yaghi, O. M. Carbon Capture and Conversion Using Metal-Organic Frameworks and MOF-Based Materials. Chem. Soc. Rev. 2019, 48 (10), 2783-2828. https://doi.org/ $10.1039 / \mathrm{c} 8 \mathrm{cs} 00829 \mathrm{a}$.

(20) Flaig, R. W.; Osborn Popp, T. M.; Fracaroli, A. M.; Kapustin, E. A.; Kalmutzki, M. J.; Altamimi, R. M.; Fathieh, F.; Reimer, J. A.; Yaghi, O. M. The Chemistry of $\mathrm{CO}_{2}$ Capture in an Amine-Functionalized MetalOrganic Framework under Dry and Humid Conditions. J. Am. Chem. Soc. 2017, 139 (35), 12125-12128. https://doi.org/10.1021/jacs. $7 \mathrm{~b} 06382$.

(21) Kim, E. J.; Siegelman, R. L.; Jiang, H. Z. H.; Forse, A. C.; Lee, J.-H.; Martell, J. D.; Milner, P. J.; Falkowski, J. M.; Neaton, J. B.; Reimer, J. A.; Weston, S. C.; Long, J. R. Cooperative Carbon Capture and Steam Regeneration with Tetraamine-Appended Metal-Organic Frameworks. Science 2020, 369 (6502), 392-396. https://doi.org/10.1126/ science.abb3976.

(22) Bhatt, P. M.; Belmabkhout, Y.; Cadiau, A.; Adil, K.; Shekhah, O.; Shkurenko, A.; Barbour, L. J.; Eddaoudi, M. A Fine-Tuned Fluorinated MOF Addresses the Needs for Trace $\mathrm{CO}_{2}$ Removal and Air Capture Using Physisorption. J. Am. Chem. Soc. 2016, 138 (29), 9301-9307. https://doi.org/10.1021/jacs.6b05345.

(23) Lin, J.-B.; Nguyen, T. T. T.; Vaidhyanathan, R.; Burner, J.; Taylor, J. M.; Durekova, H.; Akhtar, F.; Mah, R. K.; Ghaffari-Nik, O.; Marx, S.; Fylstra, N.; Iremonger, S. S.; Dawson, K. W.; Sarkar, P.; Hovington, P.; Rajendran, A.; Woo, T. K.; Shimizu, G. K. H. A Scalable Metal-Organic Framework as a Durable Physisorbent for Carbon Dioxide Capture. Science 2021, 374 (6574), 1464-1469. https://doi.org/10.1126/science.abi7281.

(24) Adil, K.; Bhatt, P. M.; Belmabkhout, Y.; Abtab, S. M. T.; Jiang, H.; Assen, A. H.; Mallick, A.; Cadiau, A.; Aqil, J.; Eddaoudi, M. Valuing Metal-Organic Frameworks for Postcombustion Carbon Capture: A Benchmark Study for Evaluating Physical Adsorbents. Adv. Mater. 2017, 29 (39), 1702953. https://doi.org/10.1002/adma.201702953.

(25) Min, K.; Choi, W.; Kim, C.; Choi, M. Oxidation-Stable Amine-Containing Adsorbents for Carbon Dioxide Capture. Nat. Commun. 2018, 9 (1), 726. https://doi.org/10.1038/s41467-018-03123-0.

(26) Lashaki, M. J.; Khiavi, S.; Sayari, A. Stability of Amine-Functionalized CO 2 Adsorbents: A Multifaceted Puzzle. Chem. Soc. Rev. 2019, 48 (12), 3320-3405. https://doi.org/10.1039/C8CS00877A.

(27) Perry, R. J.; Rainka, M. P.; Doherty, M. D.; Wood, B. R.; Namjoshi, O.; Hatchell, D.; Liu, H.; Rochelle, G. T. Thermal Degradation of 
Aminosilicone Carbamates. Energy Fuels 2016, 30 (12), 1067110678. https://doi.org/10.1021/acs.energyfuels.6b02284.

(28) Siegelman, R. L.; Kim, E. J.; Long, J. R. Porous Materials for Carbon Dioxide Separations. Nat. Mater. 2021, 20 (8), 1060-1072. https:// doi.org/10.1038/s41563-021-01054-8.

(29) Hepburn, C.; Adlen, E.; Beddington, J.; Carter, E. A.; Fuss, S.; Mac Dowell, N.; Minx, J. C.; Smith, P.; Williams, C. K. The Technological and Economic Prospects for CO2 Utilization and Removal. Nature 2019, 575 (7781), 87-97. https://doi.org/10.1038/s41586-0191681-6.

(30) Zimmermann, A. W.; Wunderlich, J.; Müller, L.; Buchner, G. A.; Marxen, A.; Michailos, S.; Armstrong, K.; Naims, H.; McCord, S.; Styring, P.; Sick, V.; Schomäcker, R. Techno-Economic Assessment Guidelines for $\mathrm{CO}_{2}$ Utilization. Front. Energy Res. 2020, 8, 5. https:// doi.org/10.3389/fenrg.2020.00005.

(31) Fracaroli, A. M.; Furukawa, H.; Suzuki, M.; Dodd, M.; Okajima, S.; Gándara, F.; Reimer, J. A.; Yaghi, O. M. Metal-Organic Frameworks with Precisely Designed Interior for Carbon Dioxide Capture in the Presence of Water. J. Am. Chem. Soc. 2014, 136 (25), 8863-8866. https://doi.org/10.1021/ja503296c.

(32) Cao, Y.; Song, F.; Zhao, Y.; Zhong, Q. Capture of Carbon Dioxide from Flue Gas on TEPA-Grafted Metal-Organic Framework $\mathrm{Mg}_{2}$ (dobdc). J. Environ. Sci. 2013, 25 (10), 2081-2087. https:// doi.org/10.1016/S1001-0742(12)60267-8.

(33) McDonald, T. M.; Lee, W. R.; Mason, J. A.; Wiers, B. M.; Hong, C. S.; Long, J. R. Capture of Carbon Dioxide from Air and Flue Gas in the Alkylamine-Appended Metal-Organic Framework mmen$\mathrm{Mg}_{2}$ (dobpdc). J. Am. Chem. Soc. 2012, 134 (16), 7056-7065. https:// doi.org/10.1021/ja300034j.

(34) McDonald, T. M.; Mason, J. A.; Kong, X.; Bloch, E. D.; Gygi, D.; Dani, A.; Crocellà, V.; Giordanino, F.; Odoh, S. O.; Drisdell, W. S.; Vlaisavljevich, B.; Dzubak, A. L.; Poloni, R.; Schnell, S. K.; Planas, N.; Lee, K.; Pascal, T.; Wan, L. F.; Prendergast, D.; Neaton, J. B.; Smit, B.; Kortright, J. B.; Gagliardi, L.; Bordiga, S.; Reimer, J. A.; Long, J. R. Cooperative Insertion of $\mathrm{CO}_{2}$ in Diamine-Appended Metal-Organic Frameworks. Nature 2015, 519 (7543), 303-308. https://doi.org/ $10.1038 /$ nature 14327.

(35) Milner, P. J.; Martell, J. D.; Siegelman, R. L.; Gygi, D.; Weston, S. C.; Long, J. R. Overcoming Double-Step $\mathrm{CO}_{2}$ Adsorption and Minimizing Water Co-Adsorption in Bulky Diamine-Appended Variants of $\mathrm{Mg}_{2}$ (dobpdc). Chem. Sci. 2017, 9 (1), 160-174. https://doi.org/10. 1039/C7SC04266C.

(36) Siegelman, R. L.; Milner, P. J.; Forse, A. C.; Lee, J.-H.; Colwell, K. A.; Neaton, J. B.; Reimer, J. A.; Weston, S. C.; Long, J. R. Water Enables Efficient $\mathrm{CO}_{2}$ Capture from Natural Gas Flue Emissions in an Oxidation-Resistant Diamine-Appended Metal-Organic Framework. J. Am. Chem. Soc. 2019, 141 (33), 13171-13186. https://doi.org/ $10.1021 /$ jacs.9b05567.

(37) Queen, W. L.; Hudson, M. R.; Bloch, E. D.; Mason, J. A.; Gonzalez, M. I.; Lee, J. S.; Gygi, D.; Howe, J. D.; Lee, K.; Darwish, T. A.; James, M.; Peterson, V. K.; Teat, S. J.; Smit, B.; Neaton, J. B.; Long, J. R.; Brown, C. M. Comprehensive Study of Carbon Dioxide Adsorption in the Metal-Organic Frameworks $\mathrm{M}_{2}$ (dobdc) $(\mathrm{M}=\mathrm{Mg}, \mathrm{Mn}, \mathrm{Fe}, \mathrm{Co}, \mathrm{Ni}$, $\mathrm{Cu}, \mathrm{Zn}$ ). Chem. Sci. 2014, 5 (12), 4569-4581. https://doi.org/ 10.1039/C4SC02064B.

(38) Furukawa, H.; Gándara, F.; Zhang, Y.-B.; Jiang, J.; Queen, W. L.; Hudson, M. R.; Yaghi, O. M. Water Adsorption in Porous Metal-Organic Frameworks and Related Materials. J. Am. Chem. Soc. 2014, 136 (11), 4369-4381. https://doi.org/10.1021/ja500330a.

(39) Vlaisavljevich, B.; Odoh, S. O.; Schnell, S. K.; Dzubak, A. L.; Lee, K.; Planas, N.; Neaton, J. B.; Gagliardi, L.; Smit, B. $\mathrm{CO}_{2}$ Induced Phase
Transitions in Diamine-Appended Metal-Organic Frameworks. Chem. Sci. 2015, 6 (9), 5177-5185. https://doi.org/10.1039/ C5SC01828E.

(40) Choi, S.; Watanabe, T.; Bae, T.-H.; Sholl, D. S.; Jones, C. W. Modification of the $\mathrm{Mg} / \mathrm{DOBDC} \mathrm{MOF}$ with Amines to Enhance $\mathrm{CO}_{2}$ Adsorption from Ultradilute Gases. J. Phys. Chem. Lett. 2012, 3 (9), 1136 1141. https://doi.org/10.1021/jz300328j.

(41) Kreutzer, J.; Blaha, P.; Schubert, U. Assessment of Different Basis Sets and DFT Functionals for the Calculation of Structural Parameters, Vibrational Modes and Ligand Binding Energies of $\mathrm{Zr}_{4} \mathrm{O}_{2}$ (Carboxylate $)_{12}$ Clusters. Comput. Theor. Chem. 2016, 1084, 162-168. https://doi.org/10.1016/j.comptc.2016.03.030.

(42) Pirngruber, G. D.; Carlier, V.; Leinekugel-le-Cocq, D. Post-Combustion $\mathrm{CO}_{2}$ Capture by Vacuum Swing Adsorption Using Zeolites - a Feasibility Study. Oil Gas Sci. Technol. - Rev. D'IFP Energ. Nouv. 2014, 69 (6), 989-1003. https://doi.org/10.2516/ogst/2012067.

(43) Krishnamurthy, S.; Rao, V. R.; Guntuka, S.; Sharratt, P.; Haghpanah, R.; Rajendran, A.; Amanullah, M.; Karimi, I. A.; Farooq, S. $\mathrm{CO}_{2}$ Capture from Dry Flue Gas by Vacuum Swing Adsorption: A Pilot Plant Study. AIChE J. 2014, 60 (5), 1830-1842. https://doi.org/10.1002/ aic. 14435 .

(44) Jiang, J.; Gándara, F.; Zhang, Y.-B.; Na, K.; Yaghi, O. M.; Klemperer, W. G. Superacidity in Sulfated Metal-Organic Framework-808. J. Am. Chem. Soc. 2014, 136 (37), 12844-12847. https://doi.org/10.1021/ ja507119n.

(45) Lide, D. R. CRC Handbook of Chemistry and Physics: A Ready-Reference Book of Chemical and Phyical Data, 72nd ed. (1991-92 ed.).; CRC Press: Boca Raton, FL, 1991.

(46) Dawson, R. M. C. Data for Biochemical Research; Clarendon Press: Oxford, 1959.

(47) Brownson, J. R. S.; Tejedor-Tejedor, M. I.; Anderson, M. A. FTIR Spectroscopy of Alcohol and Formate Interactions with Mesoporous $\mathrm{TiO}_{2}$ Surfaces. J. Phys. Chem. B 2006, 110 (25), 12494-12499. https://doi.org/10.1021/jp0614547.

(48) Ji, P.; Solomon, J. B.; Lin, Z.; M. Wilders, A.; Jordan, R. F.; Lin, W. Transformation of Metal-Organic Framework Secondary Building Units into Hexanuclear Zr-Alkyl Catalysts for Ethylene Polymerization. J. Am. Chem. Soc. 2017, 139 (33), 11325-11328. https:// doi.org/10.1021/jacs.7b05761.

(49) Zheng, H.-Q.; Liu, C.-Y.; Zeng, X.-Y.; Chen, J.; Lü, J.; Lin, R.-G.; Cao, R.; Lin, Z.-J.; Su, J.-W. MOF-808: A Metal-Organic Framework with Intrinsic Peroxidase-Like Catalytic Activity at Neutral PH for Colorimetric Biosensing. Inorg. Chem. 2018, 57 (15), 9096-9104. https://doi.org/10.1021/acs.inorgchem.8b01097.

(50) Formic acid, sodium salt https://webbook.nist.gov/cgi/cbook.cgi? $\mathrm{ID}=\mathrm{B} 6010183 \&$ Units=SI\&Mask=80\#IR-Spec (accessed 2021-0731).

(51) Hossain, M. I.; Cunningham, J. D.; Becker, T. M.; Grabicka, B. E.; Walton, K. S.; Rabideau, B. D.; Glover, T. G. Impact of MOF Defects on the Binary Adsorption of $\mathrm{CO}_{2}$ and Water in UiO-66. Chem. Eng. Sci. 2019, 203, 346-357. https://doi.org/10.1016/j.ces.2019.03.053.

(52) Toth, J. State Equation of the Solid-Gas Interface Layers. Acta Chim. Acad. Sci. Hung. 1971, 69 (3), 311-328.

(53) Vaidya, P. D.; Kenig, E. Y. CO2-Alkanolamine Reaction Kinetics: A Review of Recent Studies. Chem. Eng. Technol. 2007, 30 (11), 14671474. https://doi.org/10.1002/ceat.200700268. 
Table of Contents (TOC)

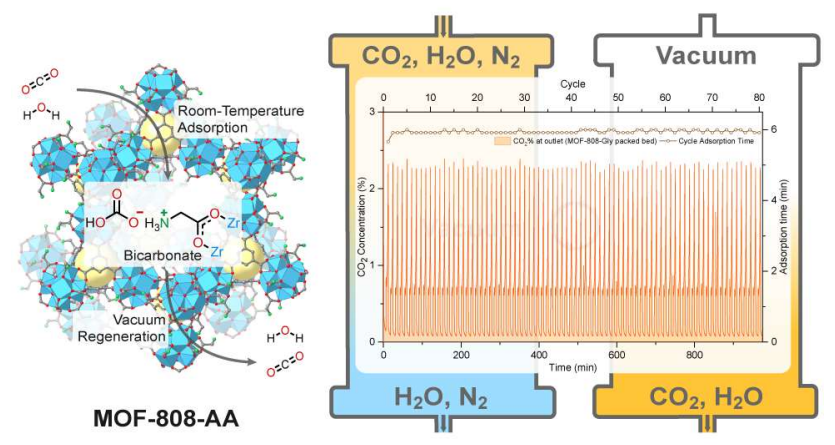

